\title{
Identifikasi Jamur Rizosfer Pada Tanaman Pisang Kepok (Musa paradisiaca L.) Yang Tumbuh Di Dataran Dan Perbukitan
}

\section{Identification of Rhizosphere Fungi in Banana Kepok (Musa paradisiaca L.) Plants Growing In Plains and Hills}

\author{
Ni’matuljannah Akhsan ${ }^{1}$ Surya Sila1 ${ }^{2}$, Jamilatul Hudal ${ }^{3}$ \\ 1,2,3 Program Studi Agroekoteknologi, Fakultas Pertanian, Universitas Mulawarman, \\ Jl. Pasir Belengkong, Kampus Gunung Kelua, Samarinda, Kalimantan Timur, Indonesia. \\ email: sempajaku@gmail.com, suryasila@gmail.com,jamilatulhuda115@gmail.com
}

Article Submitted : 09-11-2021

Article Accepted : 27-12-2021

\begin{abstract}
Banana is a commodity that supports food security and is also an agribusiness commodity that is cultivated in almost all countries with tropical and subtropical climates. Currently, the productivity of bananas developed by the community is still very low. The productivity gap is due to improper cultivation techniques and high pest and disease-causing disturbances, especially by fungal attacks found in the rhizosphere of banana plants. The aim of the study was to identify the rhizosphere fungus on the kepok banana plant that grows in the plains and hills. This research was conducted at the Laboratory of Plant Diseases Pests, Faculty of Agriculture, Mulawarman University. This research was conducted by surveying and taking soil samples. Three samples were taken from each place, so the total number of samples was 6 samples. The results of the research on the rhizosphere of the kepok banana plant that grew in the plains were Trichoderma sp., Rhizopus sp., Beauveria sp., Penicillium sp. and Aspergillus sp. with an average population of $30 \times 103$ CFU/g and the hills found the fungus Pythium sp., Trichoderma sp., Colletotrichum sp. and Fusarium sp. population mean $23.6 \times 103$ CFU/g.
\end{abstract}

Keywords: Kepok banana plantations, rhizosphere fungus, mushroom population

\section{PENDAHULUAN}

Pisang merupakan komoditas penunjang ketahanan pangan dan juga sebagai komoditas agribisnis yang dibudidayakan hampir di seluruh negara beriklim tropik maupun subtropik. Berbagai kultivar pisang dibudidayakan di Indonesia antara lain Pisang Raja, Pisang Barangan, Pisang Jambe, Pisang Raja Sere, Pisang Kepok, Pisang Bali, Pisang Mas, Pisang Lampung, Pisang Ambon (Susanto dan Saneto, 1994). Petani di Provinsi Kalimantan Timur telah membudidayakan tanaman pisang secara luas, baik di pekarangan ataupun di kebun. Produksi buah pisang Provinsi Kalimantan Timur pernah dikirim ke Pulau Jawa dan Bali mulai akhir tahun 1990 hingga awal tahun 2000. Jumlah pengiriman terbesar ke Pulau Jawa dan Bali yang tercatat melalui pelabuhan Balikpapan terjadi pada tahun 2004 yang mencapai 4.121,5 Mg. Pengiriman buah pisang dari Provinsi Kalimantan Timur tersebut terhenti pada pertengahan tahun 2000, akibat terjadinya ledakan serangan patogen. Saat ini secara umum produktivitas pisang yang dikembangkan masyarakat masih sangat rendah, yaitu hanya dibawah 10 Mgha-1, padahal potensi produktivitasnya bisa mencapai 35-40 Mgha-1. Kesenjangan produktivitas tersebut disebabkan teknik budidaya tidak tepat serta tingginya gangguan Hama dan penyebab penyakit terutama oleh serangan jamur yang terdapat di rizosfer tanaman pisang (BPPMD Provinsi Kalimantan Timur, 2013).

Mikroorganisme yang hidup pada daerah rizosfer berperan penting dalam memaksimalkan hasil tanaman pisang. Pada rizosfer tanaman pisang terdapat organisme yang bermanfaat dan organisme merugikan. Rizosfer merupakan bagian tanah yang berada di sekitar perakaran tanaman dan berperan sebagai pertahanan luar bagi tanaman terhadap serangan patogen akar. Beberapa mikroorganisme rizosfer berperan penting dalam siklus hara dan proses pembentukan tanah pertumbuhan tanaman, mempengaruhi aktivitas mikroorganisme serta sebagai pengendali hayati terhadap patogen akar. Pentingnya populasi mikroorganisme di sekitar rizosfer adalah untuk memelihara kesehatan akar, pengambilan nutrisi atau unsur hara, dan toleran terhadap stress/cekaman lingkungan pada saat sekarang telah dikenal (Kumar dkk. 2012). Populasi jamur di rizosfer biasanya lebih banyak dan beragam dibandingkan pada tanah yang bukan rizosfer (Lynch, 1983). Jamur yang hidup pada daerah rizosfer biasanya digunakan sebagai agen pengendalian hayati. Rizosfer merupakan daerah yang ideal bagi tumbuh dan berkembangnya mikroba tanah, termasuk di dalamnya adalah jamur (Julyanda, 2011). Kehadiran sejumlah populasi jamur dapat mempengaruhi pertumbuhan tanaman karena dapat meningkatkan produktivitas tanaman dan mempertahankan kesuburan tanah. Penggunaan jamur antagonis sebagai agen pengendali biologi dapat menekan perkembangan penyebaran jamur (Abadi, 1987). Tujuan penelitian untuk mengetahui jamur-jamur yang terdapat pada rizosfer tanaman pisang kepok yang tumbuh di dataran dan perbukitan serta mengetahui populasi jamur yang terdapat pada rizosfer tanaman pisang kepok yang tumbuh di dataran dan perbukitan. 


\section{BAHAN DAN METODE}

\section{Bahan dan Alat.}

Waktu dan tempat Penelitian ini dilaksanakan pada bulan November 2019 hingga Februari 2020. Lokasi penelitian (a) Pengambilan sampel tanah rizosfer bertempat di Jalan Wahid Hasyim, Kelurahan Sempaja Selatan, Kecamatan Samarinda Utara, Kota Samarinda, Kalimantan Timur, (b) Identifikasi dan menghitung populasi jamur rizosfer dilakukan di Laboratorium Ilmu Hama Penyakit Tumbuhan Fakultas Pertanian, Universitas Mulawarman Samarinda, Kalimantan Timur. Alat yang digunakan dalam penelitian ini adalah peralatan gelas laboratorium, inkubator, mikroskop, pipet tetes, kamera optilab. Bahan yang digunakan dalam penelitian ini adalah sampel tanah rizosfer tanaman pisang yang tumbuh di dataran dan perbukitan, media Potato Dextrose Agar (PDA), aquades, tissue, alkohol 70\%, dan methylene blue.

\section{Prosedur Penelitian.}

Pengambilan sampel tanah di lakukan pada lahan budidaya tanaman pisang kepok yang tumbuh di datar dan perbukitan. Kriteria tanaman pisang yang akan diambil yaitu tanamannya subur, tanahnya gembur serta berwarna coklat tua. Sampel diambil dengan pengeboran tanah dengan kedalaman $30 \mathrm{~cm}$ dengan jarak lubang dari tanaman $10 \mathrm{~cm}$. Diambil 3 sampel dari masing-masing tempat, jadi jumlah sampel seluruhnya adalah 6 sampel. Kemudian dimasukan ke dalam kantong plastik klip dan diberi label, sampel tanah tersebut dibawa ke laboratorium. Kegiatan di Laboratorium mengisolasi jamur rizosfer dari sampel tanah yang dimulai dengan menimbang 1 g lalu dimasukan pada tabung reaksi yang berisi $9 \mathrm{ml}$ aquades steril, kemudian dikocok, setelah itu dari larutan tersebut, diambil $1 \mathrm{ml}$ dan dimasukan ke dalam tabung reaksi yang berisi $9 \mathrm{ml}$ aquadest steril. Hal tersebut berulang hingga mencapai tingkat pengenceran 10-3. Hasil pengenceran tersebut kemudian diambil $1 \mathrm{ml}$ dan diteteskan ke dalam cawan petri yang telah berisi media PDA yang sudah padat, selanjutnya direkatkan plastik wrap, selanjutnya diinkubasi pada suhu ruang $27-28^{\circ} \mathrm{C}$ selama 7 hari.

Pengamatan dimulai pada 3 hari setelah inokulasi dan dihitung populasi jamur yang tumbuh. Rumus yang digunakan untuk menghitung total koloni jamur yaitu Jumlah koloni percawan x 1 Faktor pengenceran dengan satuan CFU (Colony Forming Units). Dalam metode ini diasumsikan bahwa satu koloni berasal dari satu sel jamur. Jumlah jamur dalam 1 gram tanah (CFU/g) dihitung dengan membagi jumlah koloni yang tumbuh dengan faktor pengenceran (Kawuri dkk. 2007). Selanjutnya dilakukan pemurnian jamur yang ditemukan. Identifikasi jamur rizosfer dilakukan dengan mengamati Jamur di bawah mikroskop seperti bentuk dan warna koloni, hifa bersekat atau tidak, konidia dan konidiofor dibandingkan dengan buku identifikasi jamur (Domsch dkk., 1993; Samson dkk., 1984; Alexopoulos et all, 1996; Hughes, 1971). Jamur-jamur tersebut di Dokumentasi menggunakan kamera optilab.

\section{HASIL DAN PEMBAHASAN}

Hasil isolasi dan identifikasi terdapat beberapa jamur yang akan diuraikan berikut ini.

\section{Trichoderma sp.}

Berdasarkan pengamatan secara makroskopis, terlihat bahwa warna koloni jamur pada hari pertama dan kedua tampak berwarna putih. Pada hari ketiga, warna koloni mulai berubah menjadi putih kehijauan. Pada hari kempat dan berikutnya warna koloni sudah sepenuhnya berwarna hijau muda hingga hijau tua. Koloni jamur berkembang dengan cepat pada media PDA, hal ini dapat terlihat pada cawan petri. Koloni jamur pada awalnya hialin (bening atau berwarna putih) kemudian biasanya warna koloni berubah menjadi hijau karena adanya pembentukan konidium. Pengamatan secara mikroskopis yaitu hifa bersekat, konidianya berbentuk bulat atau oval, hialin, berdinding halus, dan fialid tampak langsing dan panjang. Pada beberapa spesies konidiofor dilengkapi dengan apeks, namun setiap cabang pada kebanyakan spesies diakhiri dengan fialid. Trichoderma sp. memiliki konidiofor bercabang cabang teratur, tidak membentuk berkas, konidium jorong, bersel satu, dalam kelompok - kelompok kecil terminal, kelompok konidium berwarna hijau (Gambar 1).
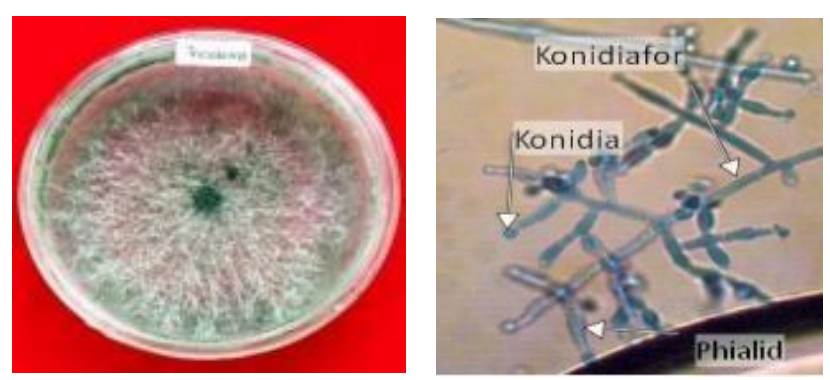

Gambar 1. Koloni (a),Konidiofor dan Konidia Trichoderma sp (400x) (b).

Berdasarkan hasil pengamatan makroskopis dan mikroskopis dan membandingkan buku identifikasi jamur maka Jamur ini adalah Trichoderma sp. Klasifikasi jamur ini, Kingdom: Fungi, Divisi: Amastigomycota, Class: Deuteromycota, Ordo: Monilialles, Family: Meliaceae, Genus: Trichoderma, Spesies: Trichoderma sp. (Alexopoulos et all, 1996).

\section{Aspergillus sp.}

Berdasarkan pengamatan secara makroskopis, terlihat bahwa warna koloni yang dihasilkan oleh jamur ini pada hari pertama dan kedua berwarna putih kecoklatan. Pada hari ketiga yaitu coklat gelap, pada hari keempat dan seterusnya warna koloni berubah menjadi warna hitam. Pengamatan secara mikroskopis yaitu terlihat bahwa jamur ini memiliki 
hifa yang tidak bersekat, konidiofor yang panjang dan konidia yang berbentuk bulat (Gambar 2). Berdasarkan hasil pengamatan dibawah mikroskop dan menggunakan buku identifikasi jamur pada penelitian ini teridentifikasi yaitu Aspergillus sp. Jamur ini mempunyai koloni yang berwarna coklat gelap hingga hitam, kepala konidia radiate, konidiofor berdinding halus, hialin namun sering bewarna coklat, fialid terbentuk pada metulae. Metulae hialin hingga coklat, kadang septat. Konidia berbentuk bulat berwarna coklat, dihiasi dengan bintik atau duri yang tidak teratur (Samson dkk., 1984). Jamur ini diklasifikasikan dalam Kingdom: Fungi,Divisi: Amastigomycota, Kelas: Ascomycetes, Ordo: Eurotiales, Family: Eurotiaceae, Genus: Aspergillus, Species: Aspergillus sp. (Alexopoulos et all, 1996).
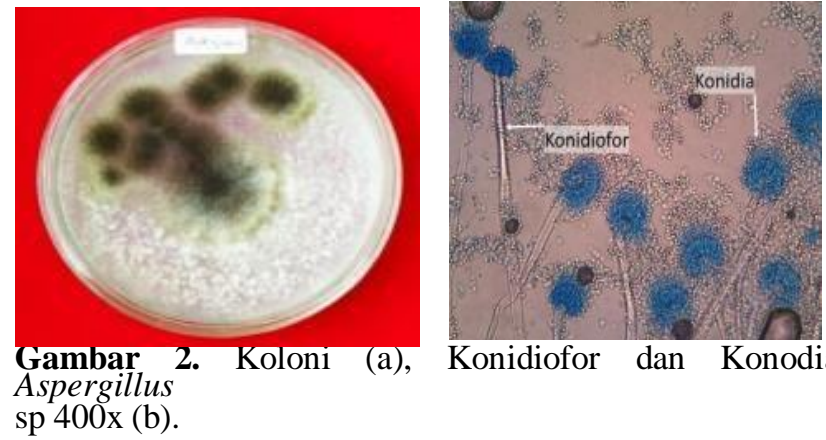

Konidiofor dan Konodia sp 400x (b)

\section{Pythium sp.}

Berdasarkan pengamatan makroskopis di Media PDA, terlihat bahwa warna koloni yang dihasilkan oleh jamur ini pada hari pertama, kedua hingga seterusnya berwarna putih,. Pengamatan secara mikroskopis yaitu terlihat bahwa jamur ini mempunyai sporangium yang berbentuk bulat atau lonjong (Gambar 3). Berdasarkan hasil pengamatan dibawah mikroskop dan menggunakan buku identifikasi jamur maka hasil dentifikasi yaitu Phytium sp. Jamur Pythium sp. mempunyai miselium yang ramping dan kasar, klamidiospora dan hifa somatik. Sporangiumnya terbentuk dibagian ujung atau kebanyakan dibagian tengah sporangiofor (Samson dkk., 1984). Jamur Pythium sp. diklasifikasikan dalam Kingdom: Fungi, Divisi: Mastigomycotina, Kelas: Oomycetes, Ordo: Peronosporales, Family: Phytiaceaea, Genus: Pythium, Species: Pythium sp. .(Alexopoulos et all, 1996).
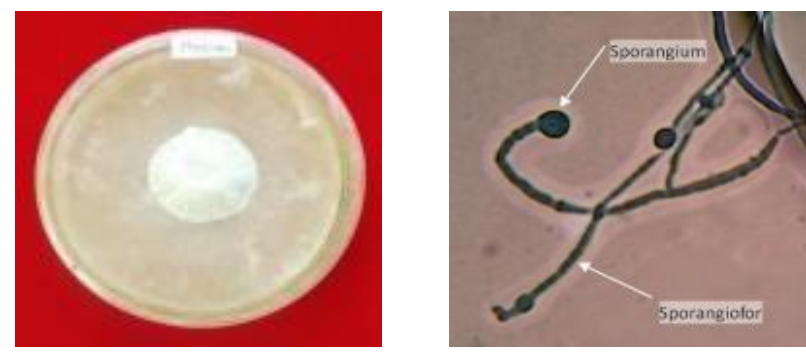

Gambar 3. Koloni (a), Konidiofor dan Konidia Pythium sp. $400 x(b)$

\section{Fusarium sp.}

Berdasarkan hasil pengamatan secara makroskopis di media PDA, tampak koloni jamur ini berwarna putih pada hari ketiga, setelah hari keempat dan seterusnya warna koloni berubah menjadi putih kekuningan. Pengamatan secara mikroskopis yaitu terlihat bahwa jamur ini memiliki dua jenis konidia yaitu mikrokonidia dan makrokonidia. Jamur ini mempunyai konidia yang berbentuk lancip, ujungnya melengkung seperti bulan sabit, memiliki sekat dan ada juga yang tidak bersekat (Gambar 4). Berdasarkan hasil pengamatan dibawah mikroskop dan menggunakan buku identifikasi jamur pada penelitian ini teridentifikasi yaitu Fusarium sp. Koloni jamur Fusarium sp. biasanya tumbuh dengan cepat, berwarna putih pudar atau berwarna cerah seperti kuning, merah muda, kecoklat-coklatan, kemerahan, violet atau berwarna ungu, mempunyai mikro dan makrokonidia. Miselia tampak jarang atau banyak seperti kapas, kemudian menjadi seperti beludru (Samson dkk., 1984). Jamur ini diklasifikasikan dalam Kingdom: Fungi, Subkingdom: Dikarya, Filum: Ascomycota, Subfilum: Pezizomycotina, Kelas: Ascomycetes, Ordo: Hypocreales, Family: Nectriaceae, Genus: Fusarium, Species: Fusarium sp. (Alexopulos et all, 1996).
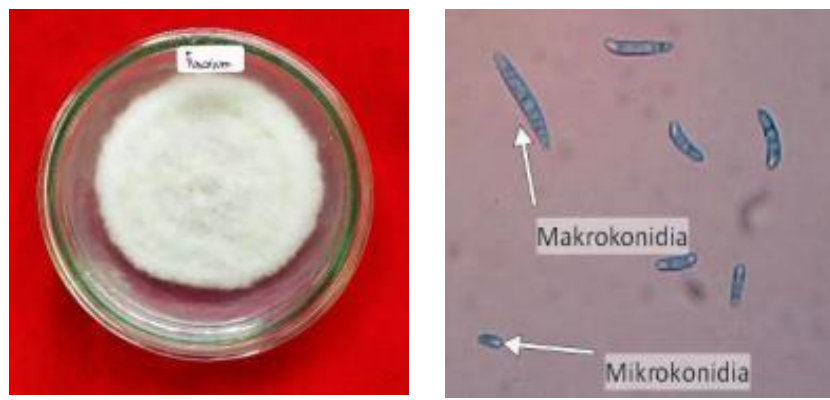

Gambar 4. Koloni (a), Makro dan Mikrokonidia Fusarium sp.(400x)

\section{Penicillium sp.}

Berdasarkan pengamatan secara makroskopis di Media PDA, terlihat bahwa warna koloni jamur berwarna putih kehijauan dengan permukaan koloni seperti kapas. Pengamatan secara mikroskopis yaitu terlihat bahwa jamur ini mempunyai konidiofor hialin tegak, bercabang, fialid meruncing, konidia berwarna hijau pucat berbentuk ellips (Gambar 5). Berdasarkan hasil pengamatan dibawah mikroskop dan menggunakan buku identifikasi jamur pada penelitian ini teridentifikasi yaitu Penicillium sp. (Samson dkk., 1984). Konidiofor tunggal terdiri dari satu stipe, memiliki cabang dan metulae. Semua sel antara metulae dan stipe disebut sebagai cabang. Pengamatan secara mikroskopis terlihat bahwa jamur Penicillium sp. memiliki konidiofor, tegak, agak kasar, berbentuk bulat atau subglobose dan bersel satu serta kepala fialid tajam memiliki hifa bersekat atau bersepta, miselium bercabang, biasanya tidak berwarna. Memiliki konidiofor bersekat dan muncul di atas permukaan, berasal dari hifa di bawah 
permukaan, bercabang atau tidak bercabang, kepala yang membawa spora berbentuk seperti sapu dengan sterigmata muncul di dalam kelompok, konidium membentuk rantai karena muncul satu persatu dari sterigmata (Fardiaz, 1992). Jamur ini diklasifikasikan dalam Kingdom: Fungi, Filum: Ascomycota, Kelas: Eurotiomycetes, Ordo: Eurotiales, Family: Trichocomaceae, Genus: Penicillium, dan Spesies: Peniciliium sp. (Alexopulos et all, 1996).
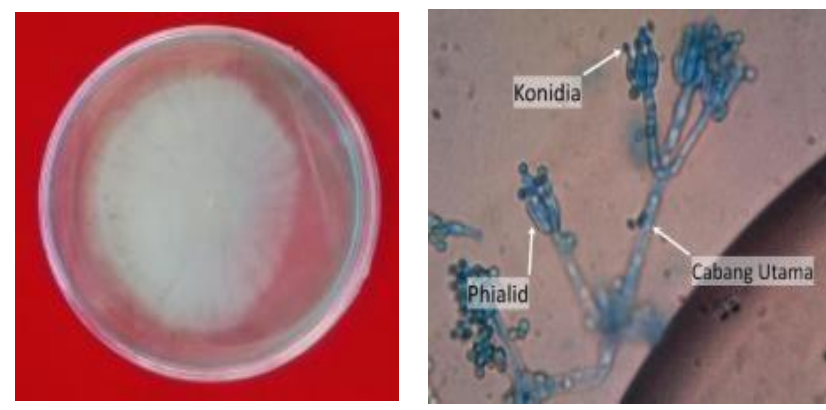

Gambar 5. Koloni (a), Phialid, Konidia, Penicillium sp. (400x)

\section{Beauveria sp.}

Berdasarkan pengamatan secara makroskopis di Media PDA, terlihat bahwa warna koloni jamur berwarna putih. Biakan yang telah bersporulasi menghasilkan kumpulan konidia seperti tepung. Pengamatan secara mikroskopis yaitu terlihat bahwa jamur ini memiliki hifa pendek, hialin lurus, dan tebal. Kelompok hifa muncul dari tengah, bentuk konidia bulat (Gambar 6). Berdasarkan hasil pengamatan dibawah mikroskop dan menggunakan buku identifikasi jamur pada penelitian ini teridentifikasi yaitu Beauveria sp. (Samson dkk., 1984). Koloni jamur Beauveria sp. biasanya berwarna putih, konidia bulat, hialin, bersel satu, terbentuk secara soliter pada ujung konidiofor, dan melekat pada sterigma yang pendek dengan pola pertumbuhan berselang seling, pertumbuhan konidioforanya zigzag (simpodial), memiliki hifa pendek, hialin lurus, dan tebal. Jamur ini diklasifikasikan dalam Domain: Eukaryota, Kingdom: Fungi, Subkingdom: Dikarya, Phylum: Ascomycota, Subphylum: Pezizomycotina, Class: Ascomycetes, Subclass: Hypocreomycetidae, Ordo: Hypocreales, Family: Clavicipitaceae, Genus: Beauveria, Spesies: Beauveria sp. (Hughes, 1971).
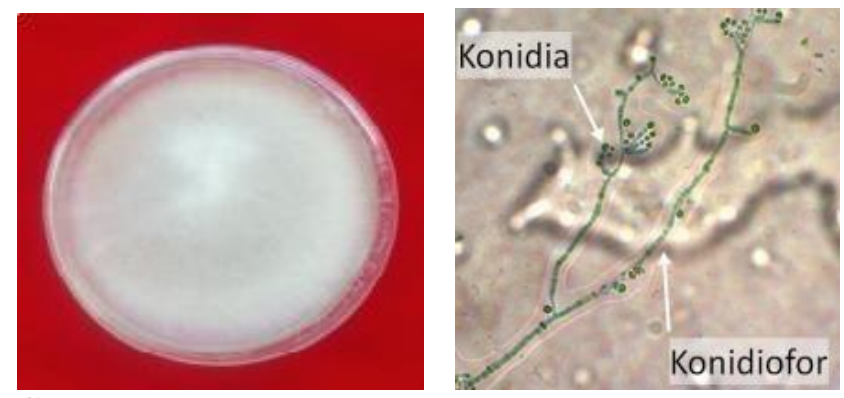

Gambar 6. Koloni (a), Konidiofor dan konidia Beauveria sp. (400x).

\section{Rhizopus sp.}

Berdasarkan pengamatan secara makroskopis di Media PDA, terlihat bahwa warna koloni jamur berwarna putih berangsur- angsur hingga abu-abu kehitaman. Pada bagian permukaan atas koloni jamur terdapat seperti butiran kasar dan pada bagian permukaan bawah berwarna hitam. Pengamatan secara mikroskopis yaitu terlihat bahwa jamur ini memiliki hifa tidak bersekat dan sporangium jamur ini berbentuk bulat (Gambar 7). Berdasarkan hasil pengamatan dibawah mikroskop dan menggunakan buku identifikasi jamur pada penelitian ini teridentifikasi yaitu Rhizopus sp. (Samson dkk., 1984).

Koloni jamur Rhizopus sp. mempunyai koloni yang berwarna keputihan menjadi abu- abu kecoklatan hingga kehitaman. Rhizoid dari jamur ini berwarna coklat, bercabang dan berlawanan arah dengan sporangiofor bisa muncul langsung dari stolon tanpa adanya rhizoid. Sporangiofor bisa satu atau berkelompok kadang-kadang menyerupai garpu, dinding berduri dan warna coklat kehitaman. Stolonnya berdinding halus atau kasar, sporangiospora jamur ini berbentuk bulat, oval atau berbentuk elips atau silinder. Spesies ini dapat tumbuh pada suhu optimum yaitu $35^{\circ} \mathrm{C}$ dengan suhu minimum $5-7^{\circ} \mathrm{C}$ dan suhu maksimum pertumbuhannya yaitu $35-44^{\circ} \mathrm{C}$ (Forbes. 1986). Jamur ini diklasifikasikan dalam Kingdom: Micetae, Divisio: Zygomycota, Class: Zygomicetes, Ordo: Mucorales, Family: Mucoraceae, Genus: Rhizopus, Spesies: Rhizopus sp. (Alexopulos et all, 1996).
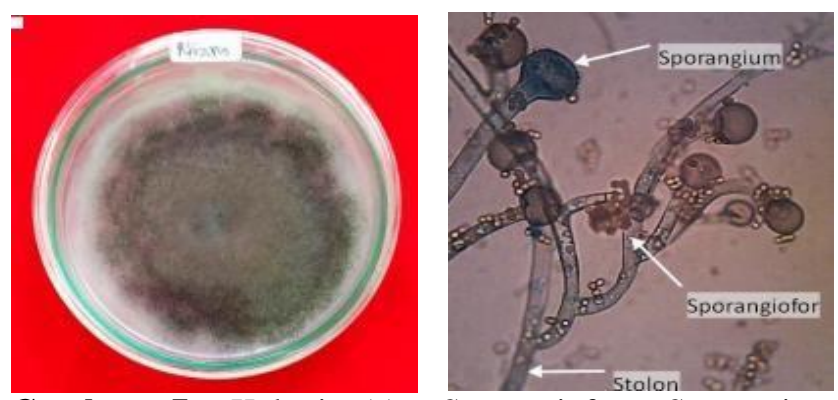

Gambar 7. Koloni (a), Sporangiofor, Sporangium Rhizopus sp. (400x)

\section{Colletotrichum sp.}

Berdasarkan pengamatan secara makroskopis di media, terlihat bahwa koloni jamur berwarna putih kecoklatan, tekstur jamur halus seperti kapas. Pengamatan secara mikroskopis yaitu terlihat bahwa jamur ini memiliki konidia tidak bersekat dan berbentuk bulan sabit (Gambar 7). Berdasarkan hasil pengamatan mikroskopis dan perbandingan dengan buku identifikasi jamur pada penelitian ini teridentifikasi yaitu Colletotrichum sp. Terlihat jamur Colletotrichum sp. memiliki spora yang menyebar, hifa tidak bersekat, menghasilkan konidia yang transparan dan memanjang dengan ujung membulat atau meruncing. Jamur Colletotrichum sp. diklasifikasikan dalam Kingdom: Fungi, Divisi: Aschomycota, Class: Ascomycetes, 
Ordo: Melanconiales, Family: Melanconiaceae, Genus: Colletotrichum, Spesis: Colletotrichum sp. (Samson dkk., 1984).
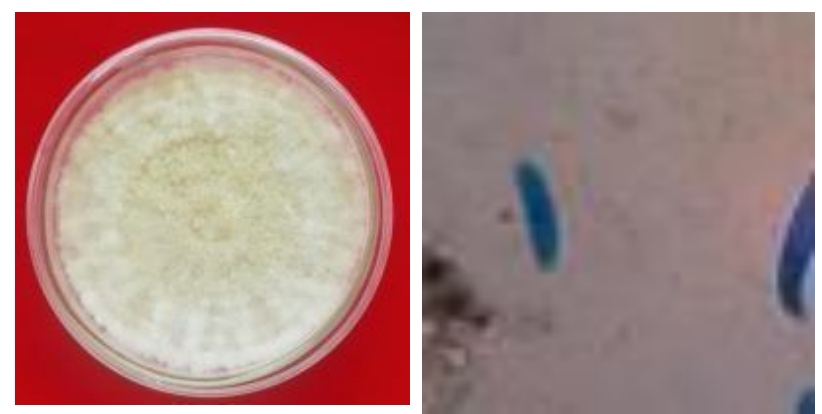

Gambar 7. Koloni (a) dan Konidia jamur Colletotrichum sp. $(400 x)$

\section{Populasi Jamur Rizosfer}

Hasil pengamatan jamur rizosfer pada tanaman pisang kepok yang tumbuh di datar dan perbukitan di peroleh 8 jenis jamur. Pada tanaman pisang kepok yang tumbuh di lahan datar terdapat 5 jenis jamur dan rata- rata populasi jamur sebesar 30 x 103 $\mathrm{CFU} / \mathrm{g}$. Pada tanaman pisang kepok yang tumbuh di perbukitan terdapat 4 jenis jamur, rata-rata populasi jamur 23,6 x 103 CFU/g. Hasil penelitian menunjukkan bahwa populasi jamur rizosfer pada lahan dataran cenderung lebih banyak dan beragam dibandingkan dengan lahan perbukitan. Hal ini dapat terjadi karena lapisan bahan organik yang berasal dari bagian perbukitan tercuci dan terbawa oleh aliran air hujan menuju daerah dataran dimana bahan organik ini merupakan salah satu sumber dari ketersediaan unsur hara.

Tabel 1. Populasi Jamur Rizosfer Tanaman Pisang Kepok Pada Daerah Dataran Dan Perbukitan

\begin{tabular}{ccc}
\hline Sampel & Populasi Jamur (CFU/g) & Jamur \\
\hline B1 & $20 \times 10^{3}$ & Colletotrichum sp. dan Trichoderma $\mathrm{sp}$ \\
B2 & $35 \times 10^{3}$ & Colletotrichum sp. dan Pythium $\mathrm{sp}$. \\
B3 & $16 \times 10^{3}$ & Trichoderma sp. dan Fusarium $\mathrm{sp}$. \\
D1 & $37 \times 10^{3}$ & Trichoderma sp. dan Rhizopus $\mathrm{sp}$ \\
D2 & $18 \times 10^{3}$ & Beauveria $\mathrm{sp}$. dan Penicillium $\mathrm{sp}$. \\
D3 & $35 \times 10^{3}$ & Trichoderma sp. dan Aspergillus $\mathrm{sp}$. \\
\hline
\end{tabular}

Keterangan: Sampel di daerah perbukitan (B), Sampel di daerah datar (D)

\section{KESIMPULAN}

Berdasarkan hasil penelitian yang dapat disimpulkan bahwa, jamur rizosfer pada tanaman pisang kepok yang tumbuh di daerah datar adalah jamur Trichoderma sp., Rhizopus sp., Beauveria sp., Penicillium sp. dan Aspergillus sp., sedangkan pada tanaman pisang kepok yang berada di daerah perbukitan adalah Pythium sp., Trichoderma sp., Colletotrichum sp. dan Fusarium sp. Populasi jamur pada daerah rizosfer tanaman pisang kepok yang tumbuh di daerah datar, rata-rata $30 \times 103$, dan ratarata populasi jamur pada daerah rizosfer tanaman pisang kepok yang tumbuh di perbukitan adalah 23,6 x 103 .

\section{DAFTAR PUSTAKA}

Abadi AL. 1987. Biologi Ganoderma boninense Pat. Pada Kelapa Sawit (Elaeis guineensis Jacq.) dan Pengaruh Beberapa Mikroba Tanah Antagonistik Terhadap Pertumbuhannya. [Disertasi]. Institut Pertanian Bogor. Bogor (ID).

Alexopoulos, C. J., Mims, C. W., and Blackwell, M. 1996. Introductory Mycology. (4th ed.). John Wiley and Sons Inc. USA
BPPMD Provinsi Kalimantan Timur. 2013. Potensi dan Peluang Investasi serta Permasalahan Komoditi Pisang di Kalimantan Timur.

Domsch, K.H., W. Gams, and T-H. Anderson. 1993. Compendium of Soil Fungi Vol. 1. IHWVerlag, Eching

Fardiaz, S. 1992. Mikrobiologi Pangan I. PT. Gramedia Pustaka Utama. Jakarta.

Forbes. 1986. Guidelines for Using "Soil Taxonomy" in The Names of Soil Map Units. Soil Conservation Service, USDA. SMSS Technical Monograph No. 10.

Hughes, S.J. 1971. Phycomycetes, Basidiomycetes, and Ascomycetes as Fungi Imperfecti. In: Taxonomy of Fungi Imperfecti (B. Kendrick, ed.). University of Toronto Press, Toronto.

Julyanda M. 2011. Keragaman Dan Kelimpahan Cendawan Pada Rizosfer Kelapa Sawit Sehat Dan Terserang Ganoderma boninense [skripsi]. Institut Pertanian Bogor. Bogor (ID).

Kawuri, R, Y. Ramona, I.B.G Darmayasa. 2007. Penuntun Praktikum Mikrobiologi Umum Untuk Study Farmasi F MIPA UNUD. 
Laboratorium Mikrobiologi Jurusan Biologi F MIPA Universitas Udayana. Bukit Jimbaran.

Kumar A, Devi S, Patil S, Payal C, Negi s. 2012. Isolation, screening and characterization of bacteria from Rhizospheric soils for diffrent plant growth promotion (PGP) activities: an in vitro study. Recent Research in Science and Technology. 4(1):1-5.

Lynch JM. 1983. Soil Biotechnology: Microbiological Factors in Crop Productivity.
Blackwell Scientific Publication. London (GB).

Samson, R.A; Hoekstra, E.S; van Ooschoot, C.A.N. 1984. Introduction To Food Borne Fungi. Institute of The Royal Netherlands Academic of Arts and Sciences. The Netherlands.

Susanto, T. dan B. Saneto. 1994. Teknologi Pengolahan Hasil Pertanian. Bina Ilmu. Surabaya. 